\title{
NATURAL RECOVERY OF MAN-MADE DISTURBANCES IN THE WEST SIBERIAN ARCTIC AND RECOMMENDED SPECIES FOR REHABILITATION
}

\author{
Olga V. Khitun \\ Komarov Botanical Institute, Russian Academy of Science, Russia
}

\begin{abstract}
Vast areas in the Arctic are faced with widespread threats ranging from gas and oil development to tourism (Sippola et al., 1995; Crawford, 1997; Forbes et al., 2001). East European and West Siberian parts of Russian Arctic have important resources of gas and oil and, thus, experience intensive mechanical impacts. By the mid-1990s, off-road transportation connected with geological prospecting had already resulted in severe damage of parts of the Yamal Peninsula. Yamal ecosystems are characterised by extreme vulnerability and low restoration potential. The rate and patterns of their natural recovery depend on the severity of the disturbance, latitudinal position and habitat type. Though only $4.5 \%$ of the local flora species in surroundings of Bovanenkovo gas field (central Yamal) can be considered as active colonizers, natural recovery is conducted only by aboriginal species. Adventitious element, wh ich is common at disturbed sites in the Boreal zone, was not found. The main problem of recultivation in the northern parts of Yamal is the absence of appropriate seed material. The planted seeds of southern grasses get completely extinct after 1 or 2 winters. Only local species (Deschampsia glauca, Poa alpigena, Arctagrostis latifolia, Calamagrostis neglecta) should be used. The study of natural recovery has showed that recommended sets of species should be site specific. Along with grasses, sowing mixtures should include sedges and forbs (different sets for sandy and loam soils). Transplanting seedlings or vegetatively reproduced young plants (especially for sedges) give good survival results. Use of willow cuttings is very promising but appropriate species (Salix lanata, S. reptans) should be chosen.
\end{abstract}

\section{INTRODUCTION}

Vulnerable arctic ecosystems are faced with widespread threats ranging from gas and oil development to recreation and tourism (Krjuchkov, 1994; Crawford, 1997; Watson et al., 2002). East European and West Siberian parts of Russian Arctic have important resources of gas and oil and, thus, experience intensive mechanical impacts (Vilchek \& Bykova, 1992; Khitun, 1997; Forbes, 1999). By the mid 1990s, off-road transportation connected with geological prospecting had already resulted in severe damage of parts of the Yamal and Tazovsky peninsulas: surroundings of Yamburg, Bovanenkovo, Kharasavei, Novii Port (Fig. 1). 
KALMAR ECO-TECH'03

Bioremediation and Leachate Treatment

KALMAR, SWEDEN, November 25-27, 2003
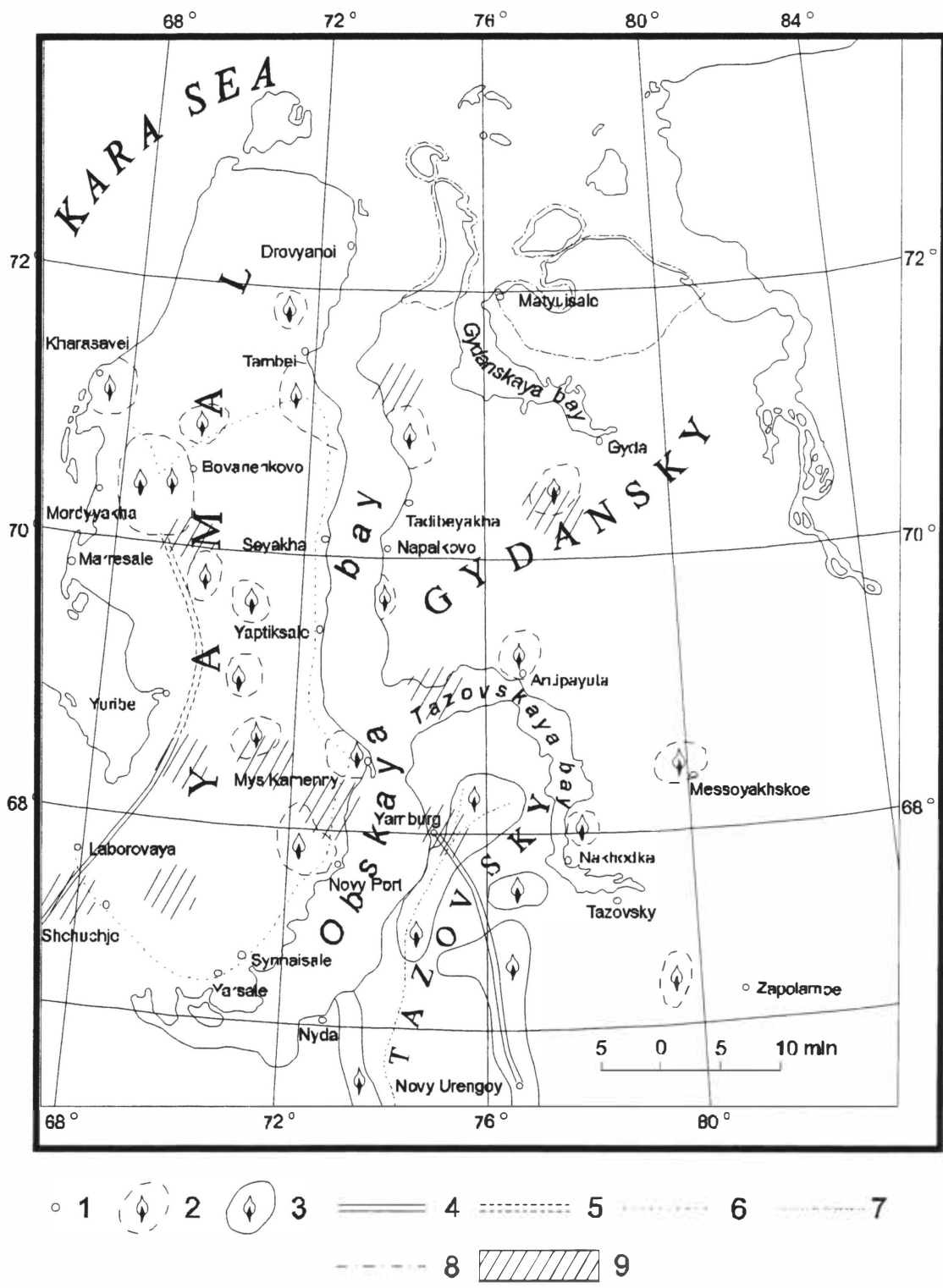

Figure 1. Industrial land-use in the West Siberian Arctic (partly compiled from: Vilchek\& Bykova, 1992). The legend: 1-permanent settlements and trading posts; 2-gas field under geological prospecting; 3-gas fields under exploitation; 4-railroad under exploitation; 5 -rails under construction; 6 - winter roads; 7 - pipeline under exploitation; 8-boundaries of Gydansky Nature Reserve; 9 -places of concentration of rare plant species (our own data). 
Damage caused by industrial activities overlaps with transformation of vegetation cover caused by overgrazing. Reindeer herding is the main occupation of indigenous population and the number of both state and private reindeer exceed the potential carrying capacity of pastures more than 1.5 times (Dobrinskii, 1995). In the central Yamal we recorded the presence of graminoid-dwarf-shrub- lichen-moss tundras replacing the typical lichen dominated zonal variant. The increased abundance of grasses in zonal communities is also the feature of transformation (Khitun, 1997). In plant cover the crustose lichens on dead moss sod were rather abundant, whereas the most valuable as reindeer forage fruticose lichens were in bad condition (low, broken, dead). Withdraw on pastures for the purposes of oil \& gas industry worsens the ecological situation in the region. Bovanenkovo gas field occupies more than 20000 ha but the area under impact of associate human activities exceeds this square 6 times. Construction of the railway in the south of Yamal opens the areas which were practically inaccessible before to uncontrolled visiting, which may have negative effect on populations of rare plants and wildlife. Barbarian hunting and fishing around the builders camps and settlements have already caused the disappearance of some local populations of rare birds and fish (Dobrinski, 1995). In surroundings of settlements within Bovanenkovo gas field we did not find 20 plant species occurring on southern slopes in non-disturbed adjacent localities (Khitun, 1997).

\section{STUDY AREA AND METHODS}

Ecosystems of the West Siberian Arctic are characterised by relatively low diversity, extreme vulnerability and low restoration potential. That is the reflection of the environmental conditions and the history of the region. The territory is a low plain with gentle rolling relief, with numerous lakes, creaks and extensive mires. Geologically this area is relatively young. Its Quaternary history has been associated with successive marine transgressions and regressions, when the terrain was re-inhabited by plants from the adjacent mainland. The bedrock is covered by up to $300 \mathrm{~m}$ thick layer of Quaternary deposits (clay, clayey and sandy grounds) (Sisko, 1977). The whole area lies within continuous permafrost zone. Construction works is difficult here due to high ground ice content, presence of ice wedges and lenses, predominance of fine-grained sediments, tixotropy of grounds. Human-induced and natural disturbances of insulating plant cover trigger natural exogenic processes and cause intensive thermodenudation. Estimation of the resilience of soil-plant cover of Yamal tundra based on its resistance and tolerance showed that the majority of biogeocenoses belongs to very weak and weak resilience categories (Zvereva, 1997). Severe climatic conditions (average January temperature vary in the region from west to east $-23^{\circ} \mathrm{C}$ to $-28^{\circ} \mathrm{C}$ and average July temperature vary from south to north from $11^{\circ} \mathrm{C}$ to $5{ }^{\circ} \mathrm{C}$ ) make revegetation of disturbed sites very slow.

The main goal of our study was to follow unassisted recovery after anthropogenic and natural mechanical disturbances and find the most promising species for rehabilitation. Natural ability of different plant communities to restore after man-made disturbances was studied in the surroundings of Bovanenkovo gas field in central Yamal $\left(70^{\circ} 17^{\prime} \mathrm{N}\right)$ in the subzone of northern hypoarctic tundra ${ }^{1}$. The period of recovery vary from $2-5$ to 20 years

\footnotetext{
'Subzonal division follows: Yurtsev, 1994.
} 
KALMAR ECO-TECH'03

Bioremediation and Leachate Treatment

KALMAR, SWEDEN, November 25-27, 2003

after the impact (Rebristaya and others 1993; Khitun and Rebristaya, 1997; Khitun 1997). More than 100 plots $0.5 \times 10 \mathrm{~m}$ were installed in several replicas inside trails left after one or several passages of tracked vehicles along mesotopographic gradient 4 years before our study, on peat heaps, at the bottom of sand excavation pit and in adjacent undisturbed communities. Also recovery was investigated on natural cryogenic landslides of known age. List of species, abundance and projective cover of each species, its phenology and vitality were recorded.

\section{RESULTS}

Responses of plant communities depend on moisture conditions and intensity of impact (Fig.2). Mesic tundra is rather tolerant to $1-3$ passes of tracked vehicle, whereas in sedge wet meadows, sphagnum bog and willow copses plant cover is severely disturbed even after 1 passage. On the other hand, wetlands have rather high restoration ability due to abundance of plants with high regeneration potential (rhizomatous, with dormant buds, with fast growing shoots) and after 5-6 years may have even higher total cover due to increased abundance of sedges.

No community can survive numerous passages. The most dramatic effect they had on shrub-dominant vegetation. Multiply passage tracks were colonised with Horsetail (Equisetum arvense) $^{2}$, Alpine Meadow Bistort (Polygonum viviparum), sedge (Carex concolor) and willow (Salix glauca, S. lanata) shoots. Mosses from adjacent natural community (Drepanocladus uncinatus, Plagiomnium medium, Aulacomnium palustre, A. turgidum) spread along with pioneer ones (Ditrihum cylindricum, Anisothecium vaginale, Bryum sp.). If wet peat is exposed, Horsetail, Arctic Dock (Rumex arctica), Bluegrass (Poa alpigena), Bulblet Saxifraga (Saxifraga cernua), Tall Jacob's Ladder (Polemonium acutiflorum), Frigid Coltsfoot (Petasites frigidus), Stellaria crassifolia and cloudberry (Rubus chamaemorus) are successfull colonizers. Zonal dwarf-birch-willowgraminoid-lichen-moss communities on the interfluve plateaus do not resist to numerous passages of heavy vehicles and recover slowly. Less than $5 \%$ of the track was revegetated 5 years after impact by Reed-Grass (Calamagrostis holmii, C. lapponica), Foxtail (Alopecurus alpinus), Hairgrass (Deschampsia glauca), Carex arctisibirica. In abandoned 20 years prior to our survey transportation corridor in the conditions of altered drainage cotton-grass dominated community with presence of Carex arctisibirica, Foxtail, Bluegrass, Arctic Dock, Alpine Meadow Bistort and willows with total projective cover up to $95 \%$ was recorded. This corridor was easily noticeable at the background of surrounding zonal community. Frost-boiled tundra with prostrate dwarfshrubs on plateau edge was the most resistant, but when finally disturbed, especially if tractor made a tum, practically no re-vegetation was noticed due to the draught of substrata. Similar responses were found on steep slope with dwarf-birch-grass-moss tundra where initial vegetation was totally damaged. Deflation was recorded in these two habitat types. Recovery in such habitats takes dozens of years.

\footnotetext{
${ }^{2}$ Nomenclature of vascular plants follows: "Arctic Flora of the USSR", and of Bryophytes: Afonina \& Chernyadjeva, 1995.
} 


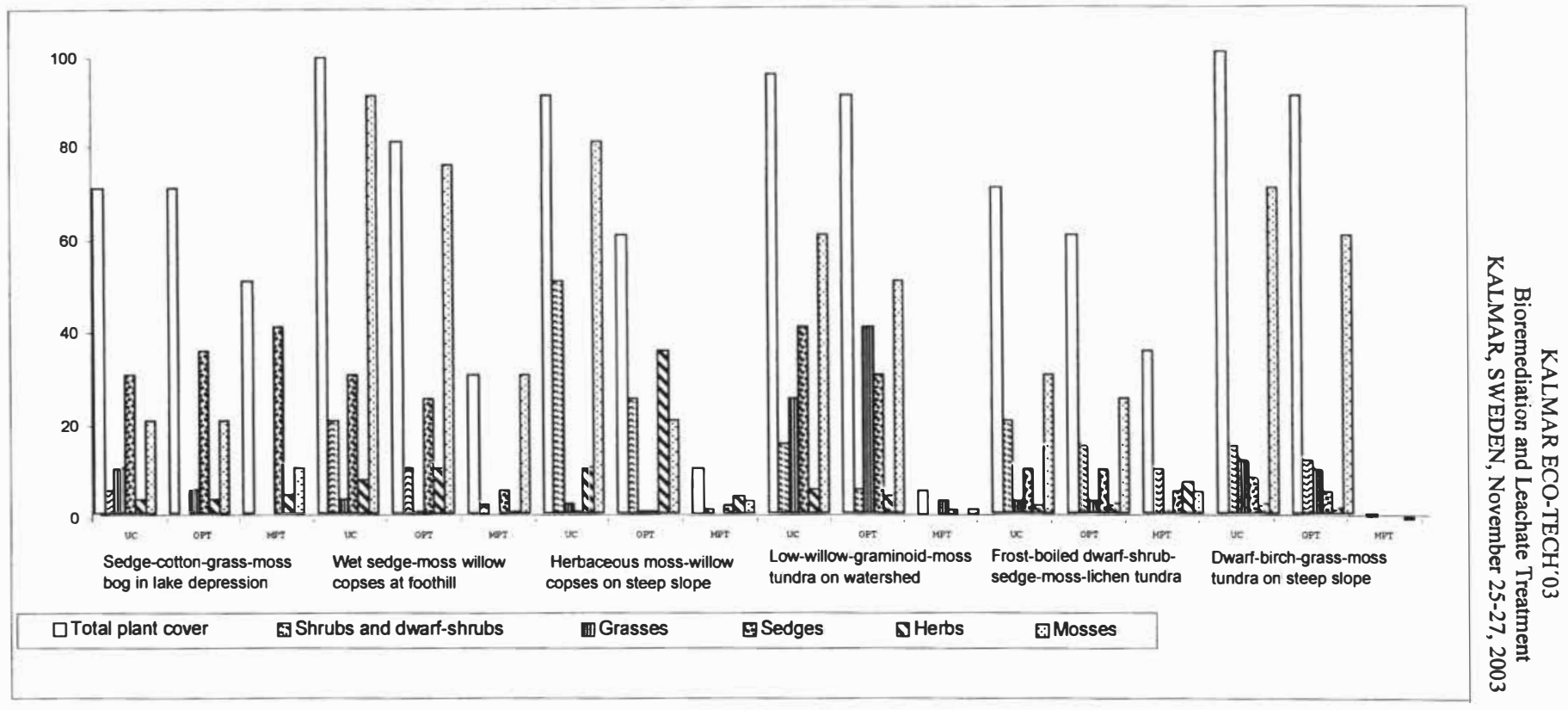

Figure 2. Responses of different plant communities along mezotopographic gradient to disturbances of different intensity in central Yamal: UC -undisturbed community (control), OPT-one-pass track, MPT-multiply-pass track. Observations were made 5-7 years after impact. 


\section{KALMAR ECO-TECH'03}

Bioremediation and Leachate Treatment

KALMAR, SWEDEN, November 25-27, 2003

In abandoned 5 years before our study, sand borrow pit, relatively moist bottom was successfully colonized (with cover up to $65 \%$ ) by patches of pioneer vegetation: Horsetail, vigorous tussocks of Alkali Grass (Puccinellia sibirica), mosses (Funaria hygrometrica, Psilopilum laevigatum) - in dryer microsites and Alaska cotton (Eriophorum scheuchzeri), Arctophila fulva, moss Anisothecium vaginale - in microdepressions, whereas on its dry slopes only few shoots (cover less than 1\%) of grasses (Festuca ovina, Poa alpigena), Horsetail and Funaria hygrometrica were recorded. The stockpiles of excavated sand with levelled surface were completely barren and subjected to aeolian erosion.

Unusually warm and wet summers in 1988-1989 accelerated the initiation of numerous activelayer detachment slides in vicinities of Bovanenkovo (Rebristaya et al., 1995). Landslides occurred on slopes with different aspect and inclination more than $1.5^{\circ}$. Their length varied from dozen of meters to $600-700 \mathrm{~m}$, and width from several meters to $40-60 \mathrm{~m}$. Presence of anthropogenic mechanical disturbances of insulating vegetative cover accelerated the natural cryogenic processes. The recovery of slides takes a very long time. Plant cover on fresh landslides 4 years after their formation was only $1-3 \%$. Rate of recovery depends on the area of the scar, its moisture status (clay surface often gets very dry) and availability of diasporas of suitable colonisers (absent in adjacent intact tundra). Normally in 10-15 years rather dense forb-grass (Tripleurospermum hookeri, Senecio congestus, Puccinellia sibirica, Deschampsia borealis) pioneer community is formed on the surface of landslide. Gradually the scar surface becomes more concave, transported blocks with initial tundra vegetation smooth down, thin top-soil layer forms, drainage conditions change and sedges (Carex concolor, C. glareosa) and Tall Cotton Grass spread onto the scar, whereas pioneers start to drop out. In 15-20 years willows (partly from remnants of transformed blocks, partly from adjacent community) expand on the slide surface.

\section{DISCUSSION}

Rate of unassisted recovery is slower in the central Yamal than in its southern parts or on the Tazovsky Peninsula. The subzonal position (northern hypoarctic tundra) should be taken into account when rehabilitation strategy has to be found. The methods of rehabilitation which were shown as prospective in forest-tundra and in southern hypoarctic tundra cannot be immediately transferred into conditions of Bovanenkovo or Kharasavei gas fields. That depends on harsh climatic conditions, instability of moisture conditions on disturbed surfaces, irregular seed formation, general paucity of flora and little portion in local flora of pioneer species able to colonize disturbed surfaces. Natural geocryological instability in this part of the peninsula worsens the situation. Study of natural recovery let us to point out the most sensitive habitats: exposed to wind erosion tops of sandy hills, steep slopes of valleys or hollows with herbaceous meadow-like vegetation, shrub thickets on foothills or in the river valleys. Our study of recovery on landslides (Rebristaya et al., 1995) along with work of dendrochronologist (Arefiev, 1994) and geocryologist (Ukraintzeva, 1996) revealed that high (up to $1 \mathrm{~m}$ ) willow thickets on gentle slopes in Bovanenkovo vicinities indicate salinity of grounds (i.e. ancient slides) and secondary transformed relief and, therefore, the danger of acceleration of solifluction and active-layer failures induced by human impact.

Recovery inside tracks is ongoing as secondary succession at expense of vegetatively mobile rhizomatous grasses and sedges present in adjacent undisturbed community, spreading into 


\section{KALMAR ECO-TECH'03}

Bioremediation and Leachate Treatment

KALMAR, SWEDEN, November 25-27, 2003

tracks or regenerating from intact rhizomes, remained below the track. Totally 46 vascular plant species were found colonizing tracks in different habitats. Revegetation of spatial disturbances (sand borrow pits) where no propagules have preserved is ongoing as primary succession due to seed rain at expense of r-strategy species common on naturally eroded sites throughout long-lasting stage of forb-grass community. 23 species were recorded in sand borrow pits.

Recovery after anthropogenic disturbance in the West Siberian sector of the Arctic goes by expense of local flora. 60 species (about $40 \%$ of local flora numbering 136 species) were found to colonize anthropogenic disturbances in the central Yamal, that is approximately 2-3 times fewer than in the European part of Arctic (Khitun 1997). By our estimation (Khitun, 1997 ) only $8 \%$ of flora can be referred to the group of active colonizers. These species should be of primary attention, when seed mixtures for sowing on rehabilitating lands are prepared (Table 1). The majority of species met in disturbed sites plays a very small role in the recovery. This is an extra evidence of the low ability of the Yamal ecosystems for recovery. The subzonal specific is reflected in the fact, that secondary communities in central Yamal are poorer than initial ones. In southern hypoarctic tundra and in forest-tundra the opposite was recorded due to the important role of apophytes and anthropochores (i.e. weeds, exotic species). In the central Yamal the latter are absent due to the climatic barrier. Another typical for the subzone feature is the geographical structure of flora. Arctic element is predominant both in the local flora on a whole and in the set of species, found on the disturbed sites (Khitun, 1997; Khitun and Rebristaya, 1997). More to the south, in the East European Arctic and in the foresttundra parts of the Western Siberia, boreal species prevail among active colonizers. Neglecting of this specifics is one of the reasons for numerous unsuccessful attempts of recultivation in the Bovanenkovo and Kharasavei surroundings.

\section{CONCLUSIONS AND RECOMMENDATIONS}

Though the arctic species are the most numerous in flora composition, in natural communities of the West Siberian Arctic they are usually not abundant. The reason is the wide spread of acidic peat soils, unfavorable for them. Disturbances result in partial or complete destruction of the organic layer, changing $\mathrm{pH}$ from strongly acidic to almost neutral, mineralization of substrata and, actually, make edaphic conditions more favourable for the arctic species. Arctic species are among the most active colonisers of landslides and even to the southern parts of the Yamal peninsula they spread by disturbed habitats. Respectively, inclusion of these local species is very important for successful recovery.

The majority of rehabilitating efforts was concentrated on creating of grass meadows (Martens and Younkin, 1997). Their results proved completely our expectations. All exotic (boreal) species, even vigorous after 1-2 seasons, disappeared after 3-4 seasons, whereas arctic ones exhibit good survival. 
KALMAR ECO-TECH'03

Bioremediation and Leachate Treatment

KALMAR, SWEDEN, November 25-27, 2003

\begin{tabular}{|l|l|l|}
\hline Clay grounds & Sand grounds & Exposed peat \\
\hline Puccinellia sibirica, & Poa alpigena, Festuca & Carex concolor, Eriophorum \\
Deschampsia glauca, & rubra ssp. arctica, Festuca & angustifolium, Polemonium \\
Deschampsia borealis, & ovina, Deschampsia glauca,, & acutiflorum, Rubus \\
Calamagrostis neglecta, & Luzula confusa, Tanacetum & chamaemorus, \\
Alopecurus alpinus, & bipinnatum, Oxytropis & Calamagrostis holmii, Poa \\
Arctagrostis latifolia, & sordida, Astragalus & arctica, Poa alpigena, Rumex \\
Arctagrostis arundinaceae, & subpolaris, Pachypleurum & arcticus, Nardosmia frigida. \\
Eriophorum scheuchzeri, & alpinum, Cerastium arvense, & \\
Carex arctisibirica, Carex & Polemonium boreale, Rumex & In wetter depressions: \\
glareosa, Tripleurospermum & graminifolius, Arabis & Eriophorum russeolum, \\
hookeri, Senecio congestus,, & septentrionalis, Antennaria & Dupontia fisheri, Arctophila \\
Cochlearia arctica, Artemisia & villifera & fulva \\
tilesii, Polygonum viviparum, & & \\
Astraglus subpolaris & & \\
\hline
\end{tabular}

Table 1. Species recommended for use in seed mixtures on different grounds in central Yamal

Unfortunately the biggest problem of re-vegetation of disturbed sites is the absence of appropriate seed material. The decision could be a special seed producing fields in the south of Yamal (in surroundings of Salekhard there is an agricultural scientific station), where viable seeds of local arctic species can be grown. Recovery on landslides showed the important role of safe-sites for the establishment of pioneer vegetation. On the slides displaced blocks with tundra vegetation played such role. Around them the first colonisers settled. In anthropogenically disturbed sites pieces of transplanted sod can be used as safe-sites and additional source of diaspores along with sowing grass mixtures. Broadcasting of peat with parts of rhizomes of local sedges can also be useful. Our observations on sites disturbed by reindeer herds showed that Carex arctisibirica, if some nitrification took place, changes its growth form and instead of loose mats forms dense tussocks. Another sedge, Carex glareosa, that is tolerant to salinity of grounds, can also be recommended - it often spreads over old landslide scars. To my mind, seed mixtures should include not only grasses (and not only perennials!), but also local pioneer herbs to achieve possible maximal diversity of stands (Table 1) and make them resembling natural pioneer communities and, respectively, accelerate the first stage of natural successional processes. It is important to keep in mind that arctic ecosystems are limited in nutrients, addition of fertilisers showed increase of growth rates and biomass production (Chapin \& Shaver, 1985), respectively, for the successful growth of sown meadow some repeated additions of fertiliser is necessary. In practice, often no attention is given to recultivating land after sowing. Though, it seems very expensive, but transplanting of grown in nurseries plants (especially tussock forming) can give good results. Willows seem to be underestimated in recultivation experiments. In surroundings of Yamburg (Tazovsky peninsula) some boreal willow cutting were successfully used, but they are not suitable in central Yamal, whereas local species (Salix glauca, S. lanata) showed good regenerating ability and their cuttings (willingly nursed and rooted in advance) can be strongly recommended. 


\section{REFERENCES}

[1] Arctic Flora of the USSR. I-X. 1960-1987. M.-L.: Nauka.

[2] Afionina, O.M. \& Chernjadieva, I.V. 1995. Mosses of the Russian Arctic: checklist and bibliography. Arctoa 5:99-142.

[3] Arefiev, S. P. 1994. Estimation of the state of shrubbt plants in tundras in the regions of gas condensate deposits in the Middle Yamal. In: The Development of the North and Problems of Recultivation. Proceedings of the II International conference: Syktyvkar, 2528 April, 1994. Syktyvkar. P. 117-122. (In Russian)

[4] Chapin, F.S.III and Shaver, G.R. 1985. Individualistic growth response of tundra plant species to environmental manipulations in the field. Ecology 66: 564-576.

[5] Crawford, R. M. M., ed. Disturbance and recovery in Arctic lands: en ecological perspective. Dordrecht: Kluwer Academic Press. 620 p.

[6] Dobrinskii, L. N., ed. 1995. The nature of Yamal. Ekaterinburg: Nauka. 435 p. (In Russian)

[7] Forbes, B. C. Reindeer herding and petroleum development on Poluostrov Yamal: sustainable or mutually incompatible uses? Polar Record. 35 (195): 317-322.

DOI: https://doi.org/10.1017/S0032247400015667

[8] Khitun, O. 1997. Self-recovery after technogenic and natural disturbances in the central part of the Yamal peninsula (Western Siberian Arctic). In: Crawford, R. M. M., ed. Disturbance and recovery in Arctic lands: en ecological perspective. Dordrecht: Kluwer Academic Press: 531-562.

[9] Khitun, O. V.; Rebristaya O. V. 1997. The specific of the compound of species colonizing disturbed habitats in Central Yamal. In: Development of the North and Problems of Recultivation. Proceedings of the III International Conference, 27-31 May 1996, Saint-Petersburg. Syktuvkar: Komi Scientific Center. P. 132-138.

[10] Krjuchkov V. V. 1994. Degradation of the environment above Polar Circle. Narodnoe khozjaistvo respubliki Komi 3 (1): 44-53. (In Russian)

[11] Martens, H. E. \& Younkin, W.E. 1997. Revegetation trials in Western Siberia: a five year summary. In: Development of the North and Problems of Recultivation. Proceedings of the III International Conference, 27-31 May 1996, Saint-Petersburg. Syktuvkar: Komi Scientific Center. P. 354-356. (In English)

[12] Rebristaya, O. V., Khitun, O. V and Chernyadjeva, I. V. 1993. Technogenous disturbances and natural re-establishment of vegetation in the subzone of the northern hypoarctic tundras of the Yamal peninsula. Botanicheskii zhurnal 78 (3): 122-135. (In Russian) 
KALMAR ECO-TECH'03

Bioremediation and Leachate Treatment

KALMAR, SWEDEN, November 25-27, 2003

[13] Rebristaya, O. V., Khitun, O. V., Chernyadjeva, I. V. and Leibman M. O. 1995. Dynamics of vegetation on the cryogenic landslides in the central part of Yamal. Botanicheskii zhurnal 80(4): 31-48. (In Russian)

[14] Sisko, R. K.,ed. 1977. Yamalo-Gydanskaya oblast. Leningrad: Gidrometeoizdat.e310 p. (In Russian)

[15] Ukraintzeva, N.G. 1996. Willow tundras of Yamal as an indicator of salinity of frozen grounds. In: Fundamental research of the Earth's cryosphere in Arctic and Subarctic: Proceedings of the conference. Puschino. P.\$21-122. (In Russian)

[16] Vilchek, G.E. \& Bykova, O.Yu. 1992. The origin of regional ecological problems within the Northern Tyumen oblast, Russia. Arctic and Alpine Research 24(2): 99-107. DOI: https://doi.org/10.1080/00040851.1992.12002935

[17] Watson, A., Alessa, L., Sproull, J., comps. 2002. Wilderness in the Circumpolar North: searching for compatibility in traditional, ecotourism, and ecological values; 2001 May 15-16; Anchorage, AK. Proceedings RMRS-P-26. Ogden, UT: U.S. Department of Agriculture, Forest Service, Rocky Mountain Research Station. 143 p.

[18] Yurtsev, B. A. 1994. Floristic division of the Arctic. Journal of Vegetation Science. 5: 765-776. DOI.: https:lldoi.orgl10.2307l3236191

[19] Zvereva, T.S. 1997. Resilience of soil-plant cover of Yamal tundra under mechanical stress and evaluation of its revegetation ability. In: Kuznetsova, E.G. , ed. Development of the North and Problems of Recultivation. Proceedings of the III International Confierence, 27-31 May 1996, Saint-Petersburg. Syktuvkar: Komi Scientific Center: 198202. (In Russian)

\section{FIGURES}

Figure 1. Industrial land-use in the West Siberian Arctic (partly compiled from: Vilchek\& Bykova, 1992). The legend: 1-permanent settlements and trading posts; 2 - gas field under geological prospecting; 3 - gas fields under exploitation; 4 - railroad under exploitation; 5 rails under construction; 6 -winter roads; 7 -pipeline under exploitation; 8 -boundaries of Gydansky Nature Reserve; 9 -places of concentration of rare plant species (our own data).

Figure 2. Responses of different plant communities along mezotopographic gradient to disturbances of different intensity in central Yamal: UC -undisturbed community (control), OPT - one -pass track, MPT - multiply-pass track. Observations were made 5-7 years after impact. 